symbol of the struggle of the Indian against conquest and absorption by the white race. Sitting Bull was a shaman or religious leader rather than a war chief in accordance with the dichotomy of function usual among these proples. Authentic relics of this chief are rare, although pairs of moccasins said to have belonged to him are found in collections scattered widely over America and Europe. The authorities of the Smithsonian Institution hitherto have allowed authenticity to one relic only in their collections, a sawed-off flint-lock taken at the time of his surrender. To this is now added a red clay tobacco pipe and buckskin tobacco pouch presented by the widow of Major-General James McArthur, who obtained them from the chief when he himself was a lieutenant in the Seventh U.S. Infantry. The pipe is of catlinite, the red clay of the Upper Missouri, commonly used by the Indians for this purpose, and has a long rectangular wooden stem. The pouch is 17 inches long with characteristic Sioux decorative work in glass beads and dyed porcupine quill.

\section{New Fossil Primate from Sterkfontein, South Africa}

FURTHER study of the large human-like third upper molar of which the discovery at Sterkfontein was recorded recently by J. C. Middleton Shaw in the columns of NATURE $(143,117 ; 1939)$ and a comparison with remains of the fossil Plesianthropus and Paranthropus of Broom have led to some interesting conclusions as to the possible significance of this new Sterkfontein primate. These further considerations have been discussed by Dr. Shaw in a communication to the Annals of the Transvaal Museum (20, 2; 1940). There would appear to be no doubt that the new molar belongs to neither Plesianthropus nor Paranthropus; and it differs from the third molars in all the material from fossil apes which has been described by W. K. Gregory. If, therefore, it belonged to a fossil ape, it must be concluded that that ape differed, at least so far as the upper third molar is concerned, from any ape hitherto described.

Evidence of the character of the corresponding tooth in fossil man, unfortunately, is inadequate. Dr. Shaw, however, detects certain resemblances between his tooth and that in Sinanthropus, except that it is larger and presents certain differences as to the crown, while there is, again with the same proviso as to size, a resemblance in the moderate taurodontism and smooth simple crown surfaces to certain Neanderthal specimens. Although no fossil human remains have been discovered at Sterkfontein, Dr. Shaw puts forward the tentative suggestion that the tooth of his discovery may be a relic of an early African human type, possibly of Pleistocene age and, therefore, a contemporary of Plesianthropus and Paranthropus. If this should be confirmed by further evidence, this is the first fossilized remains of man discovered in the Union of South Africa.

\section{Excavation at Gnezdovo, U.S.S.R.}

SovieT archæologists have recently made interesting discoveries during excavations at the village of Gnezdovo, near Smolensk. The vicinity is a veritable treasure-house of Slavonic monuments ; in it are up to 7,000 tumuli, numerous settlements and small towns relating to the first 1,000 years before our era. Excavations have been completed of the central town at Gnezdovo, considered by many archæologists as the original town of Smolensk. An area of 120 square yards was uncovered up to an average depth of $6 \frac{1}{2} \mathrm{ft}$. In one half of the excavated area was revealed an ancient Slavonic earthen dwelling place with a stone fireplace and hearth and many utensils. There were found bone, flint and iron implements, and primitive clay pots. Copper articles (clasps and buckles) found there indicate that the dwelling place relates to the middle of the first 1,000 years of our era.

In the other half of the site excavated was discovered a very rare burial ; lying on a funeral pyre was a half-burned woman in full attire and wearing many ornaments. Around her throat was a valuable necklace; suspended from a silver chain was a golden Byzantine coin, six highly ornamented gold medallions and five silver medallions. Below the medallions hung a number of multi-coloured beads, including silver ones. It is believed that the burial relates to the tenth century, and that the ornamentation is of Byzantine origin.

\section{Gold Mining in Wales}

MINING for gold has been carried on in various parts of Wales during the past two thousand years, but has experienced many vicissitudes and has frequently lapsed for long periods at individual workings. An attempt was made some three years ago to bring again into commercial production the Roman Deep mine at Pumpsaint, Carmarthenshire, but circumstances were adverse to the venture. According to Engineering of September 20, the plant has now passed into the hands of Messrs. George Cohen, Sons and Company, Ltd., for disposal. Local tradition says that the name 'Pumpsaint', which means five saints, is linked with a stone, having in one surface five small depressions, supposed to have been caused by the heads of five saints who used it as a pillow. Messrs. Cohen suggest that the hollows were caused by primitive ore-crushing stamps, and that the stone was part of the very early plant used at the mine.

\section{The Start of Education}

"Elementary Education: What is It?" (U.S, Office of Education, Bulletin 1940, No. 4, Part 1) is the first of four summaries which have followed a conference in 1938 on the subject. It is planned to give a bird's-eye view with relation to later studies and is valuable as presenting the views and criticisms of many teachers, though a little heavy in its methods of exposition. The general public needs to realize in simple language that the word 'education' means not pushing in information but drawing out the best that a child can do. To note among the experiences to be included in an elementary school "analysing" and "evaluating" seems rather advanced for a tender age, unless the child's determining of values provides 